\title{
Pengujian keamanan komputer kriptografi pada surat elektronik berbasis website dengan enkripsi metode MD5
}

\author{
Endang Setyawati ${ }^{1}$, Carolina Ety Widjayanti ${ }^{2}$, Ridho Ramadhan Siraiz ${ }^{3}$, \\ Hadion Wijoyo ${ }^{4}$ \\ ${ }^{1,2,3}$ Program Studi Sistem Informasi, STIKOM Yos Sudarso Purwokerto \\ ${ }^{4}$ Program Studi Sistem Informasi, STMIK Dharmapala Riau \\ E-mail : endang.setiawati@stikomyos.ac.id ${ }^{1}$, corlinaety@stikomyos.ac.id² ridho.ramahdans12@gmail.com³ \\ hadion.wijoyo@lecturer.stmikdharmapalariau.ac.id ${ }^{4}$
}

\begin{abstract}
ABSTRAK
Dengan kemajuan teknologi, sistem pelayanan diharapkan mampu meningkatkan kualitas suatu instansi pemerintahan dalam melaksanakan pelayanan untuk masyarakatnya. Setiap masyarakat pasti ingin mendapatkan pelayanan yang terbaik yang diberikan oleh suatu instansi pemerintahan. Karena dengan pelayanan yang baik kepada masyarakat maka akan membangun sebuah kepercayaan dari masyarakat kepada instansi pemerintahan tersebut. Usahausaha pun dilakukan seperti memberikan fasilitas yang menunjang untuk mempermudah petugas dalam melakukan pekerjaannya dengan cara menerapkan sistem yang telah terkomputerisasi. Pelayanan online menjadi suatu hal yang sangat dibutuhkan pada era globalisasi ini. Saat ini hampir semua hal dilakukan secara online, tentunya juga terjadi dengan pelayanan surat-menyurat. Sistem pelayanan yang sedang 2 berjalan di Desa Wangon, Banjarnegara sendiri adalah salah satu kegiatan yang belum terkomputerisasi dalam hal manajemen surat-menyurat, mulai dari membuat bebagai macam surat dan membuat laporan dari surat pelayanan tersebut. Pelayanan pada masyarakat yang selama ini terjadi di Desa Wangon berjalan dengan memberikan surat pelayanan secara langsung dari kantor Kelurahan Desa Wangon kepada warga yang sedang membutuhkan surat pelayanan, dengan cara warga datang langsung ke kantor Kelurahan untuk mengurus surat pelayanan, hal tersebut terkesan lambat dan lama karena warga harus datang secara langsung dan menunggu antrian yang ada. Dengan membangun sistem surat pelayanan online atau surat elektronik yang memanfaatkan teknologi informasi, memberikan keuntungan kepada masyarakat Desa Wangon maupun instansi dibidang pelayanan, seperti mempermudah pelayanan dari jarak jauh dan pelayanan dapat dilaksanakan dan diterima lebih cepat. Dengan dibangunnya pelayanan online maka perlu diberlakukan keamanannya juga, seperti data warga di dalam surat elektronik tidaklah terjamin dan selalu ada resiko terbuka untuk umum. Tidak menutup kemungkinan ada orang yang tidak bertanggung jawab atas penyalahgunaan surat elektronik tersebut. Untuk menguranginya, surat elektronik dapat diamankan dengan menggunakan teknik pengacakan (kriptografi, enkripsi).
\end{abstract}

Kata Kunci : Surat Elektronik, Kriptografi, Enkripsi, Website, Desa.

Abstract: With advances in technology, the service system is expected to be able to improve the quality of a government agency in providing services to its people. Every society would want to get the best service provided by a government agency. Because with good service to the community, it will build a trust from the community in these government agencies. Efforts were also made, such as providing supporting facilities to make it easier for officers to do their jobs by implementing a computerized system. Online services are something that is really needed in this era of globalization. Nowadays almost everything is done online, of course also happens with correspondence services. The service system that is currently running in Wangon Village, Banjarnegara itself is one of the activities that have not been computerized in terms of correspondence management, starting from making various kinds of letters and making reports from the service letter. Services to the community that have been happening in Wangon Village run by providing a service letter directly from the Wangon Village Village

Ciptaan disebarluaskan di bawah Lisensi Creative Commons Atribusi 4.0 Internasional.

http://journal.stmikjayakarta.ac.id/index.php/JMIJayakarta 
DOI: $10.52362 / j m i j a y a k a r t a . v 1 i 1.367$

office to residents who are in need of a service letter, by means of residents coming directly to the Kelurahan office to take care of service letters, this seems slow and long because residents must come directly and wait for the existing queue. By building an online service letter system or electronic mail that utilizes information technology, it provides benefits to the Wangon Village community and agencies in the service sector, such as facilitating long-distance services and services that can be carried out and received more quickly. With the construction of online services, security is also necessary, such as citizen data in electronic mail is not guaranteed and there is always a risk of being open to the public. It is possible that there are people who are not responsible for the misuse of the electronic mail. To reduce this, electronic mail can be secured using randomization techniques

(cryptography, encryption).

Keywords : Electronic Mail, Cryptography, Encryption, Website, Village.

\section{PENDAHULUAN}

Pelayanan adalah segala kegiatan dalam rangka pemenuhan kebutuhan dasar sesuai hak-hak dasar setiap warga negara dan penduduk atas suatu barang, jasa atau pelayanan administrasi yang disediakan oleh penyelenggara pelayanan yang terkait dengan kepentingan publik. Pelayanan merupakan jembatan bagaimana negara menjalankan fungsinya berkaitan dengan pemenuhan kebutuhan masyarakat. Penyelenggara pelayanan adalah lembaga atau petugas pelayanan baik Pemerintah Daerah maupun Badan Usaha Milik Daerah yang menyelenggarakan pelayanan. Penerima Layanan adalah perseorangan atau sekelompok orang atau badan hukum yang memiliki hak dan kewajiban terhadap suatu pelayanan.

Menurut petugas informasi dan pelayanan kantor Kelurahan Desa Wangon, pelayanan yang bersifat manual masih cukup diminati oleh beberapa masyarakat yang menginginkan jawaban secara langsung dari petugas pelayanan. Proses yang terkesan lambat dan lama masih terlihat pada pelayanan yang berjalan secara manual, hal ini dikarenakan antrian yang cukup panjang dan keterangan yang diberikan petugas pelayanan terkadang kurang sesuai.

Dengan kemajuan teknologi, sistem pelayanan diharapkan mampu meningkatkan kualitas suatu instansi pemerintahan dalam melaksanakan pelayanan untuk masyarakatnya. Setiap masyarakat pasti ingin mendapatkan pelayanan yang terbaik yang diberikan oleh suatu instansi pemerintahan. Karena dengan pelayanan yang baik kepada masyarakat maka akan membangun sebuah kepercayaan dari masyarakat kepada instansi pemerintahan tersebut. Usahausaha pun dilakukan seperti memberikan fasilitas yang menunjang untuk mempermudah petugas dalam melakukan pekerjaannya dengan cara menerapkan sistem yang telah terkomputerisasi.

Pelayanan online menjadi suatu hal yang sangat dibutuhkan pada era globalisasi ini. Saat ini hampir semua hal dilakukan secara online, tentunya juga terjadi dengan pelayanan surat-menyurat. Sistem pelayanan yang sedang 2 berjalan di Desa Wangon, Banjarnegara sendiri adalah salah satu kegiatan yang belum terkomputerisasi dalam hal manajemen surat-menyurat, mulai dari membuat bebagai macam surat dan membuat laporan dari surat pelayanan tersebut. Pelayanan pada masyarakat yang selama ini terjadi di Desa Wangon berjalan dengan memberikan surat pelayanan secara langsung dari kantor Kelurahan Desa Wangon kepada warga yang sedang membutuhkan surat pelayanan, dengan cara warga datang langsung ke kantor Kelurahan untuk mengurus surat pelayanan, hal tersebut terkesan lambat dan lama karena warga harus datang secara langsung dan menunggu antrian yang ada. Dengan membangun sistem surat pelayanan online atau surat elektronik yang memanfaatkan teknologi informasi, memberikan keuntungan kepada masyarakat Desa Wangon maupun instansi dibidang pelayanan, seperti mempermudah pelayanan dari jarak jauh dan pelayanan dapat dilaksanakan dan diterima lebih cepat. 


\section{TINJAUAN PUSTAKA}

DOI: 10.52362/jmijayakarta.v1i1.367

\section{Surat Elektronik}

Menurut (Mico Pardosi, 2001:18) Surat Elektronik adalah sarana kirim mengirim surat melalui jalur internet dengan menggunakan waktu yang sangat singkat dan cepat. Elektronik mail adalah suratmenyurat dalam internet.

2. Kriptografi

Menurut (Ariyus, 2008) Algoritma kriptografi merupakan langkah-langkah logis bagaimana menyembunyikan pesan dari orang-orang yang tidak berhak atas pesan tersebut.

\section{Enkripsi}

Menurut (Ferguson dkk, 2010) Enkripsi merupakan sebuah metode penyandian sebuah pesan atau informasi menjadi sebuah teks yang tidak dapat dibaca. Enkripsi berkaitan erat dengan kriptografi, yang merupakan sebuah metode untuk mengamankan sebuah pesan hingga tidak dapat dibaca oleh pihak ketiga. Enkripsi dapat dibagi menjadi dua proses enkripsi yang berbeda yaitu Block Cipher dan

Stream Cipher.

4. Website

Menurut (Hakim Lukmanul, 2004) Website disebut sebagai fasilitas internet, dimana mengkaitkan dokumen di lingkup lokal maupun jarak jauh. Dokumen tersebut disebut dengan web page dan link website memungkinkan pengguna bisa berpindah page (hyper text), baik diantara page yang disimpan server yang sama maupun server diseluruh dunia. Browser yang digunakan untuk mengakses dan membaca pages diantaranya Netscape Navigator, Google Chrome,

Internet Explorer, Mozila Firefox, dan lain sebagainya. 2.5. Desa

Menurut (Encyclopedia Britannica, 2015) Desa adalah komunitas yang tidak terlalu padat penduduk, dengan kegiatan ekonomi utama berupa produksi pangan dan bahan-bahan mentah.

5. Database

Menurut (Setyawati, Sarwani, Wijoyo, \& Soeharmoko, 2020) Database Management System (DBMS) merupakan Sistem pemrosesan basis data dimaksudkan untuk mengatasi kelemahankelemahan yang ada pada sistem pemrosesan berkas.

\section{METODOLOGI PENELITIAN}

Metode yang digunakan oleh peneliti dalam pengembangan sistem ini yaitu menggunakan metode prototype. 
DOI: $10.52362 /$ jmijayakarta.v1i1.367

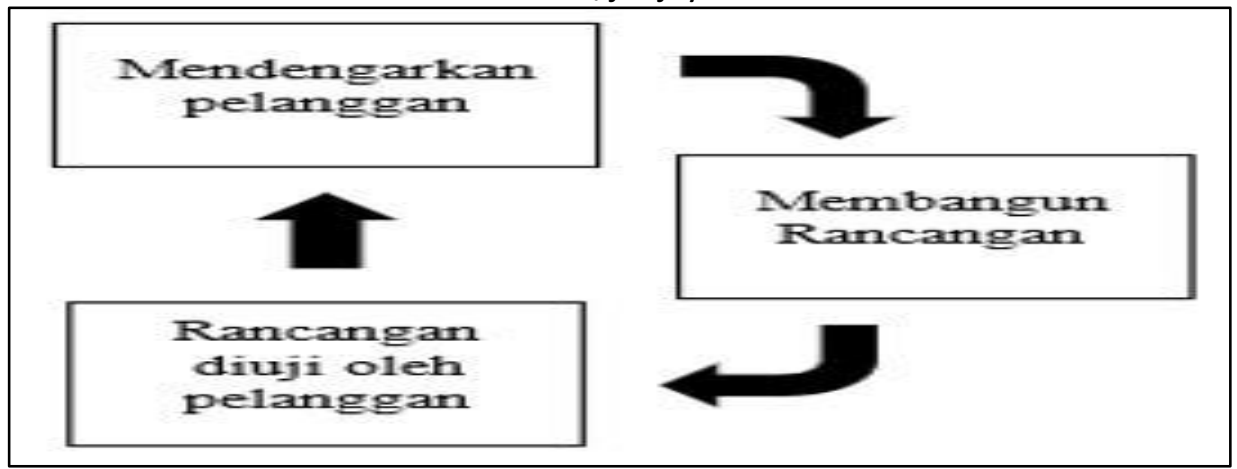

Gambar 1. Metode Prototipe.

\section{Analisis Sistem}

Pengumpulan data pada penelitian ini menggunakan teknik wawancara, yaitu peneliti atau analis berkomunikasi dengan pengguna yang berguna untuk merancang dan membangun sistem yang sesuai dengan tujuan atau keinginan dari pengguna tersebut. Metode Prototype merupakan perubahan sistem yang dapat dilakukan berkali-kali sehingga dapat mencapai kesepakatan dari sistem yang dikembangkan tersebut.

\section{Desain sistem}

Proses perancangan dari sistem yang di desain secara umum yang nantinya dikembangkan kembali. Perancangan dilakukan dengan menggunakan model analisa berorientasi objek yaitu dengan bentuk diagram-diagram. Berikut gambar dari masing-masing diagram :

a. Use Case Diagram

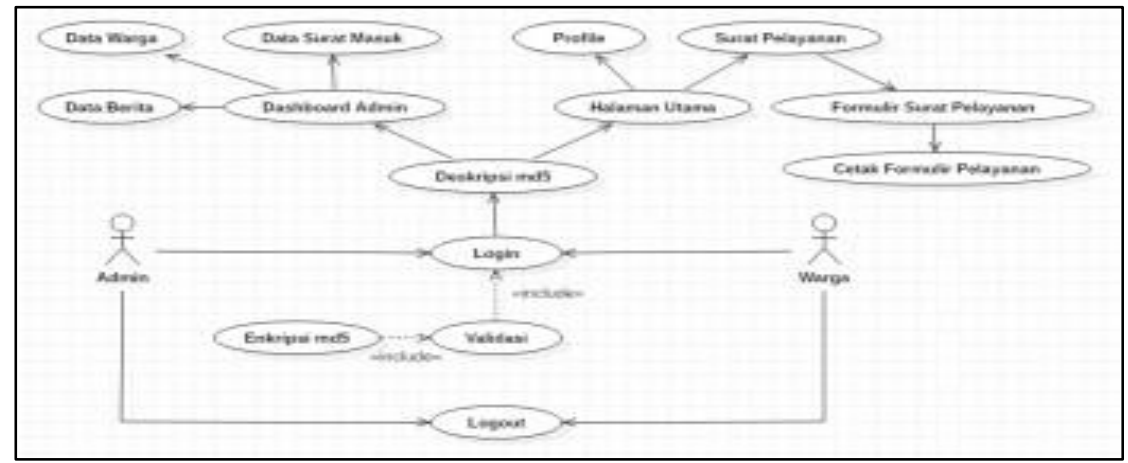

Gambar 2. Use Case

Dalam sistem surat pelayanan elektronik pada Desa Wangon terdapat 2 aktor pengguna sistem, yaitu admin (perangkat desa bagian kepengurusan surat pelayanan) sebagai pengelola sistem dan manajemen dari sistem tersebut. Warga sebagai user yang akan menggunakan sistem tersebut seperti pembuatan surat pelayanan berbasis website 
DOI: $10.52362 /$ jmijayakarta.v1i1.367

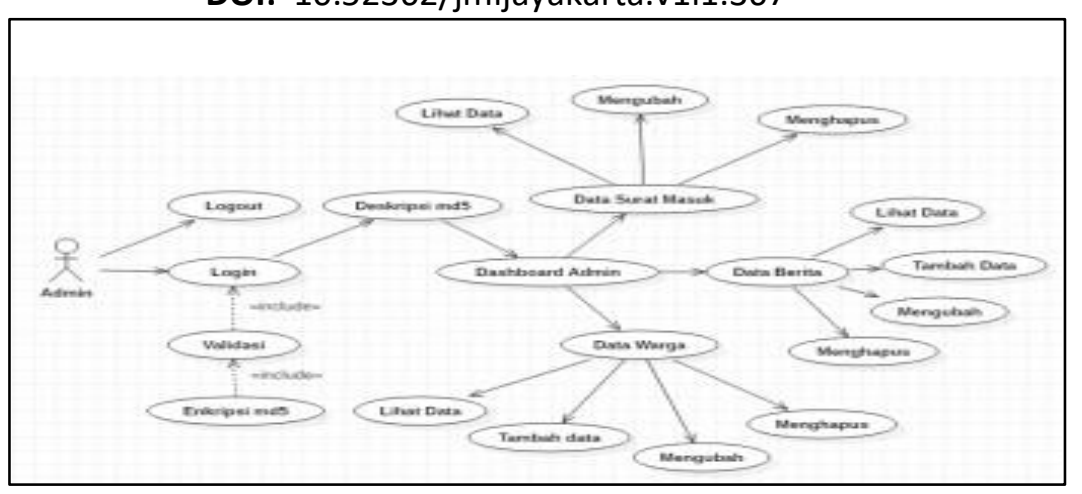

Gambar 3. Use Case Admin

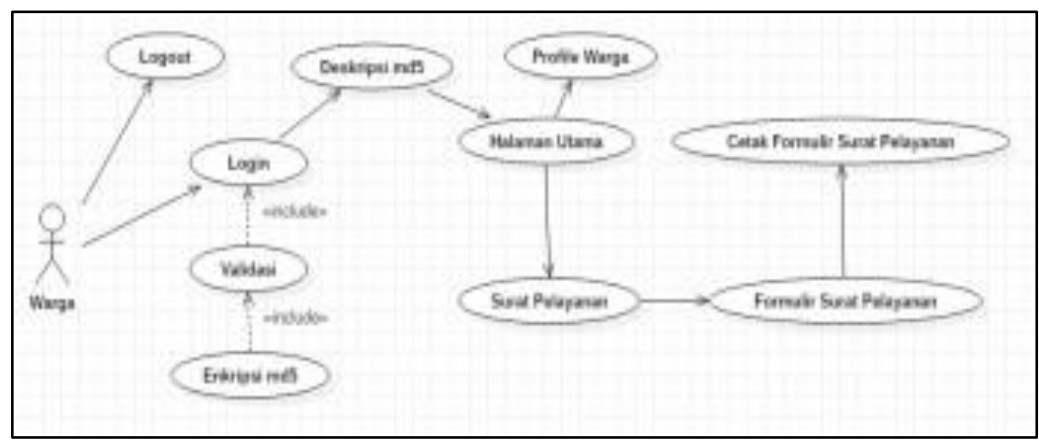

Gambar 4. Use Case Warga

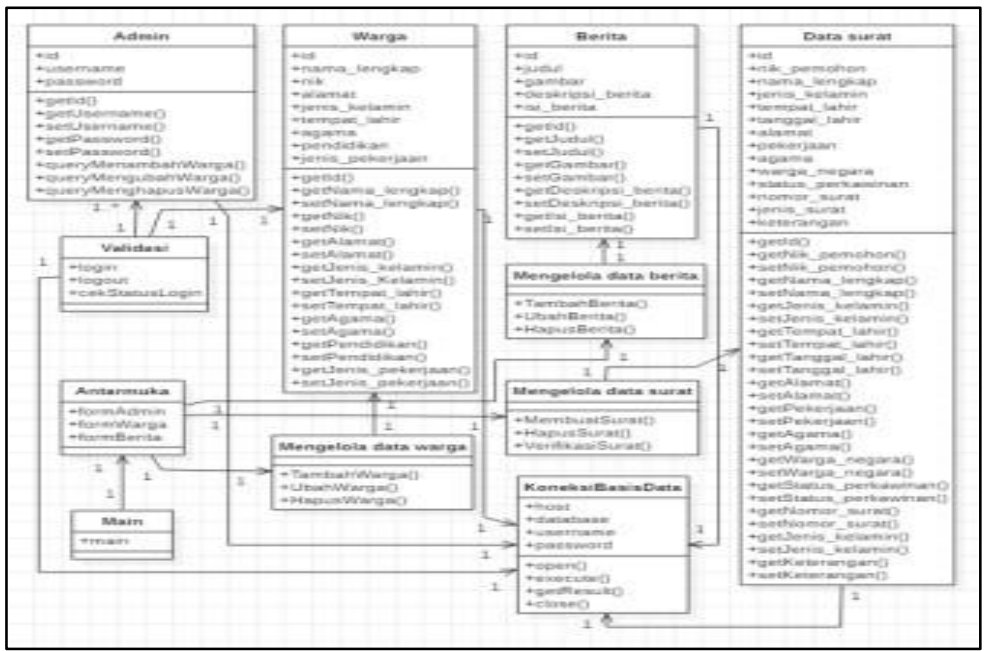

Gambar 5. Class Diagram

Pada diagram tersebut menjelaskan bahwa setiap kelas mempunyai atribut dan operasinya masing-masing. Diagram kelas merupakan diagram yang menggambarkan bagaimana bentuk, desain, isi, dan keterikatan koneksi yang ada dalam database system. 
DOI: $10.52362 /$ jmijayakarta.v1i1.367

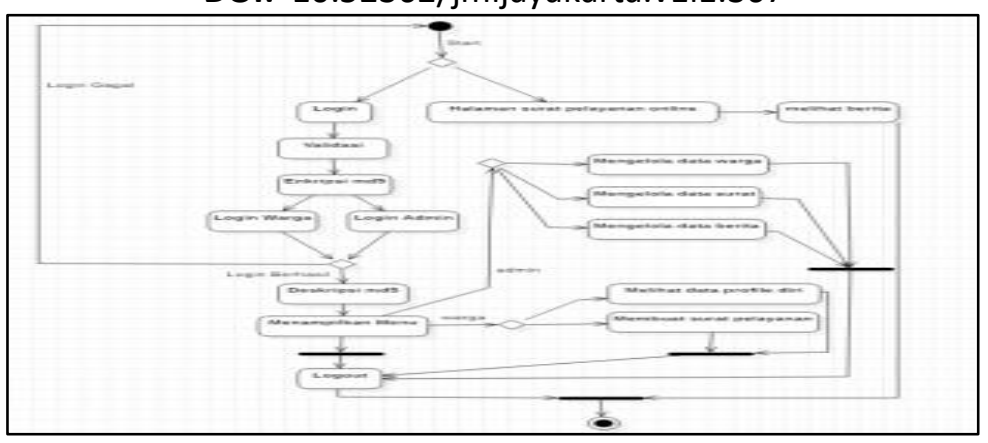

Gambar 6. Activity Diagram

Diagram User Atau Pengguna Dapat Memilih 2 Aktifitas Yaitu Melihat Halaman Informasi Desa Dan Melakukan Login. Ketika User Melakukan Login Maka Akan Divalidasi Sesuai Dengan Status User. Setelah Login Maka User Akan Masuk Ke Halaman Sesuai Dengan Status User.

\section{HASIL DAN PEMBAHASAN}

1. Hasil Pengembangan Sistem 1. Halaman Utama

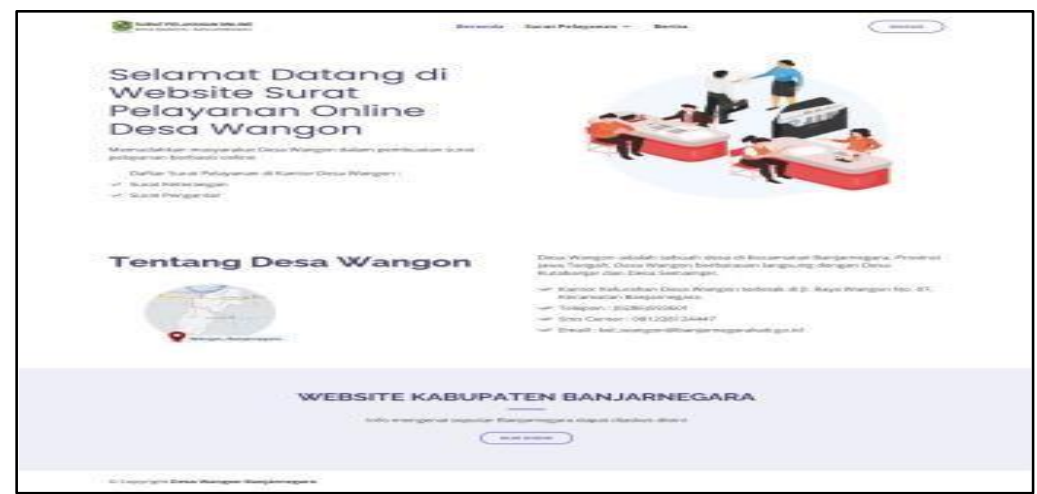

Gambar 7. Halaman Utama

2. Halaman Berita

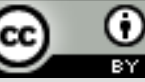

Ciptaan disebarluaskan di bawah Lisensi Creative Commons Atribusi 4.0 Internasional. http://journal.stmikjayakarta.ac.id/index.php/JMIJayakarta 
DOI: 10.52362/jmijayakarta.v1i1.367

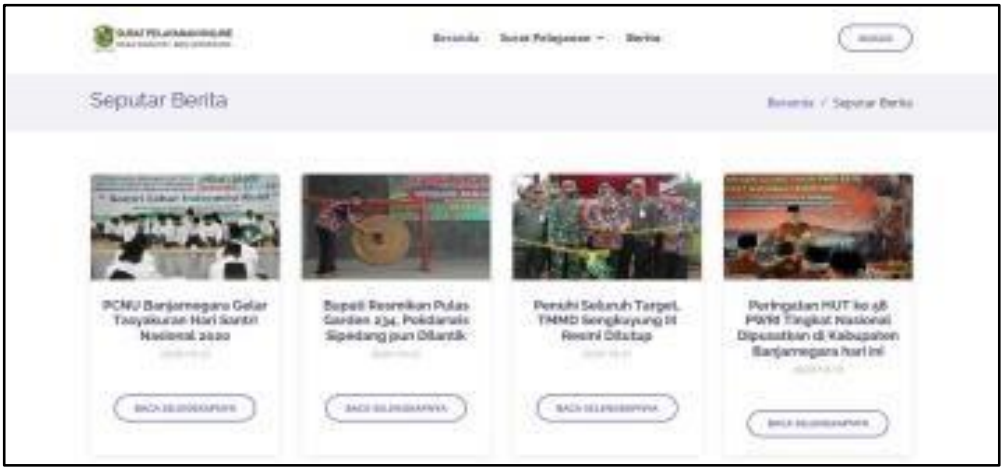

Gambar 8. Halaman Berita

3 Login Admin

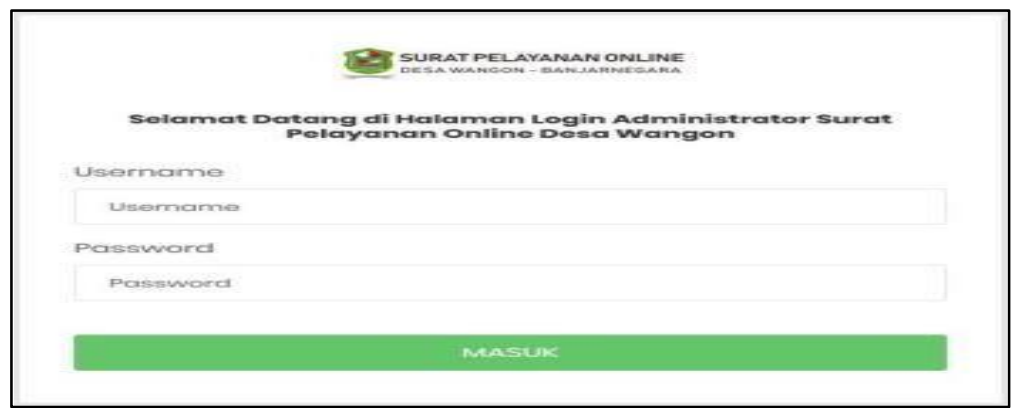

Gambar 9. Login Admin

4 Dashboard Admin

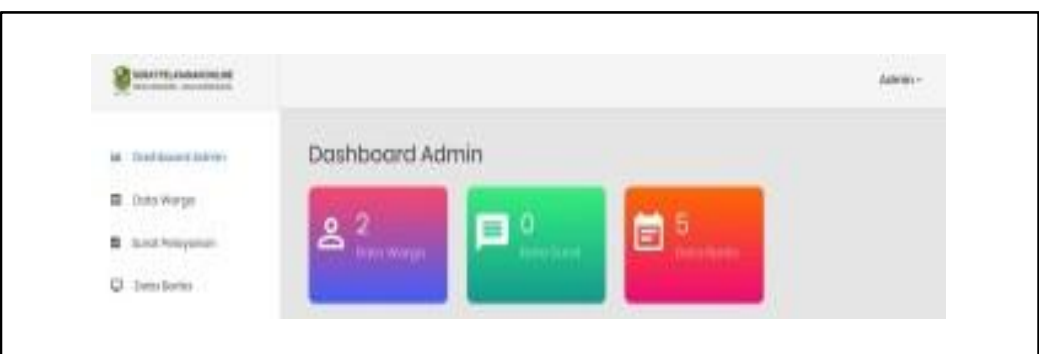

Gambar 10. Dashboard Admin

5 Halaman Data Warga

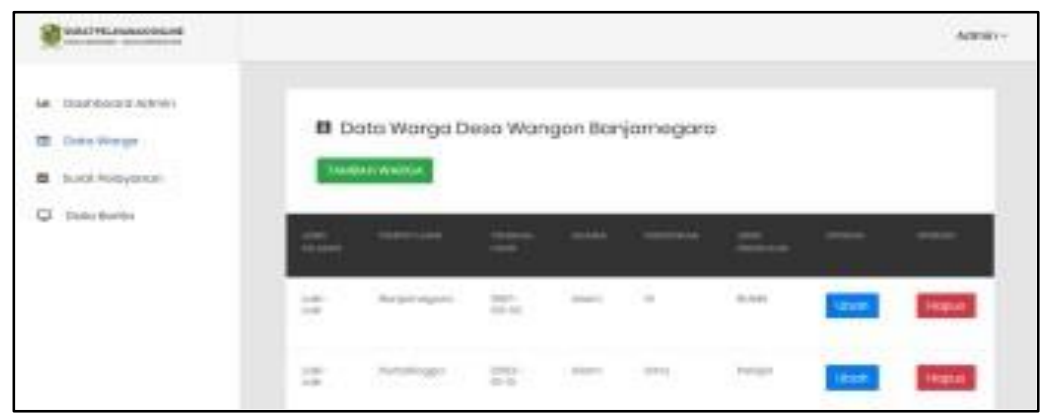

Gambar 11. Halaman Data Warga

6 Halaman Surat Pelayanan

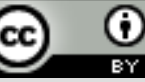

Ciptaan disebarluaskan di bawah Lisensi Creative Commons Atribusi 4.0 Internasional. http://journal.stmikjayakarta.ac.id/index.php/JMIJayakarta 
DOI: 10.52362/jmijayakarta.v1i1.367

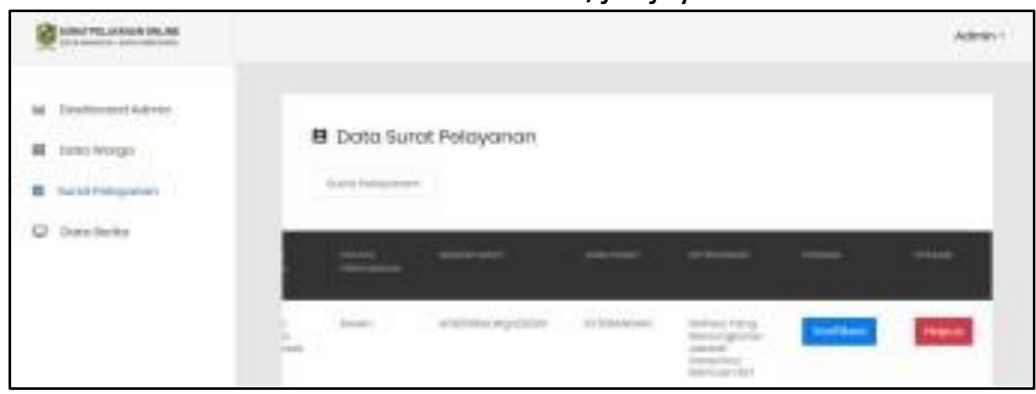

Gambar 12. HalamanSurat Pelayanan

7 Halaman Data Berita

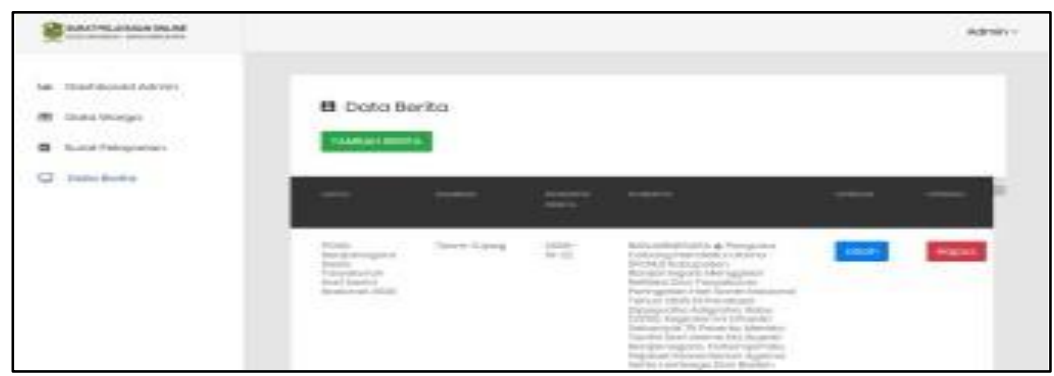

Gambar 13. Halaman Data Berita

8 Halaman Login Warga

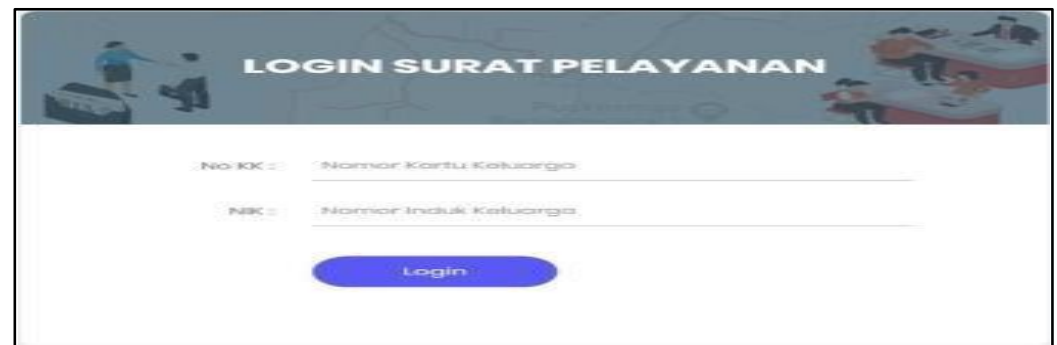

Gambar 14. Login Warga

9 Halaman surat keterangan

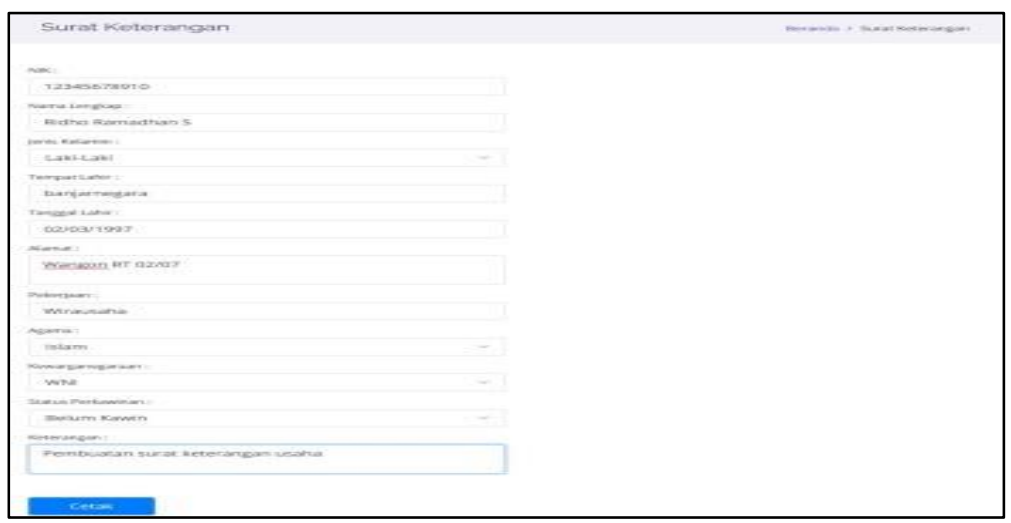

cc) (7)

Ciptaan disebarluaskan di bawah Lisensi Creative Commons Atribusi 4.0 Internasional. http://journal.stmikjayakarta.ac.id/index.php/JMIJayakarta 
DOI: 10.52362/jmijayakarta.v1i1.367

Gambar 16. Halaman Surat Keterangan

10 Halaman Surat Pengantar

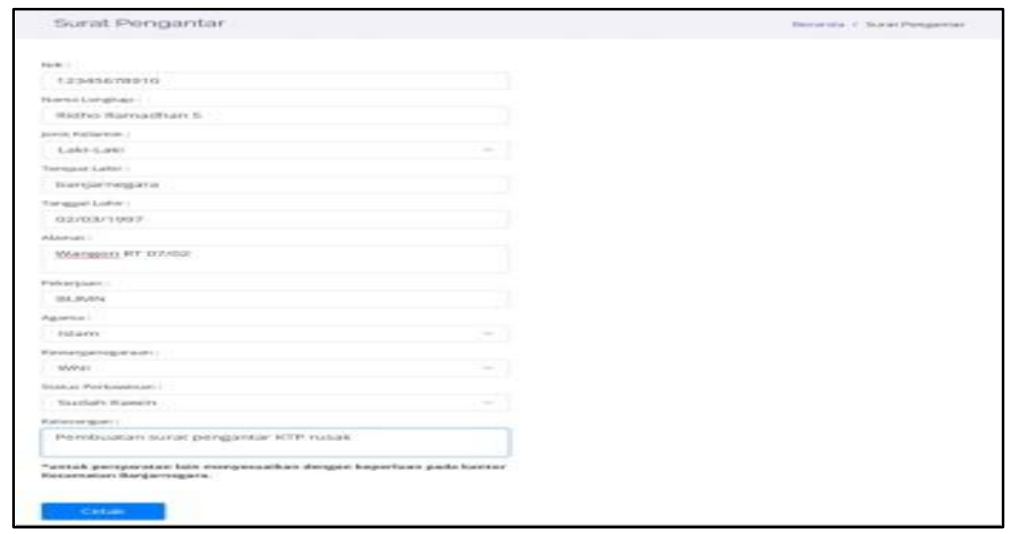

Gambar 17. Halaman Surat Pengantar

11. Cetak surat

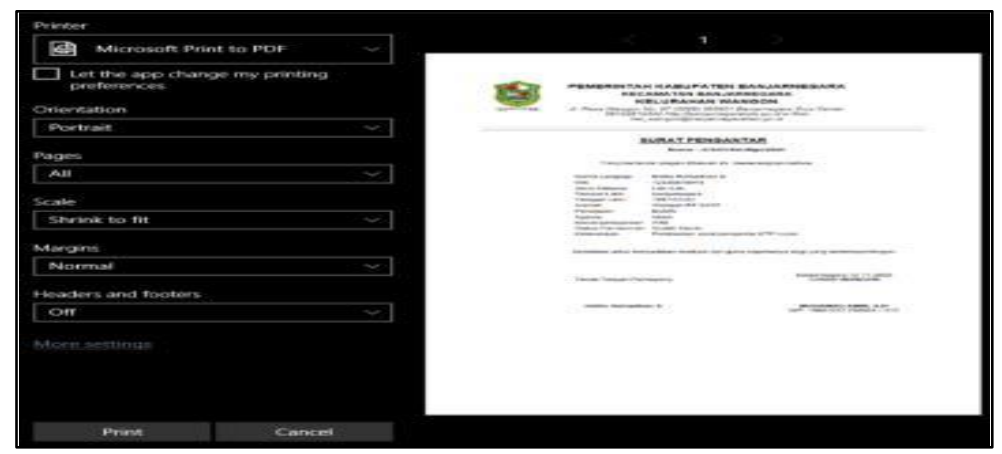

Gambar 18. Cetak Surat

12. Halaman Profil

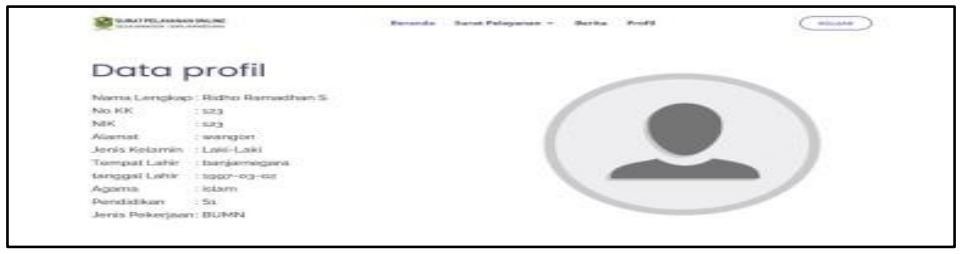

Gambar 19. Halaman Profil

13. Pengujian Sistem White Box Testing

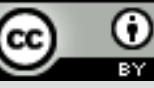

Ciptaan disebarluaskan di bawah Lisensi Creative Commons Atribusi 4.0 Internasional. http://journal.stmikjayakarta.ac.id/index.php/JMIJayakarta 
DOI: $10.52362 / j m i j a y a k a r t a . v 1 i 1.367$

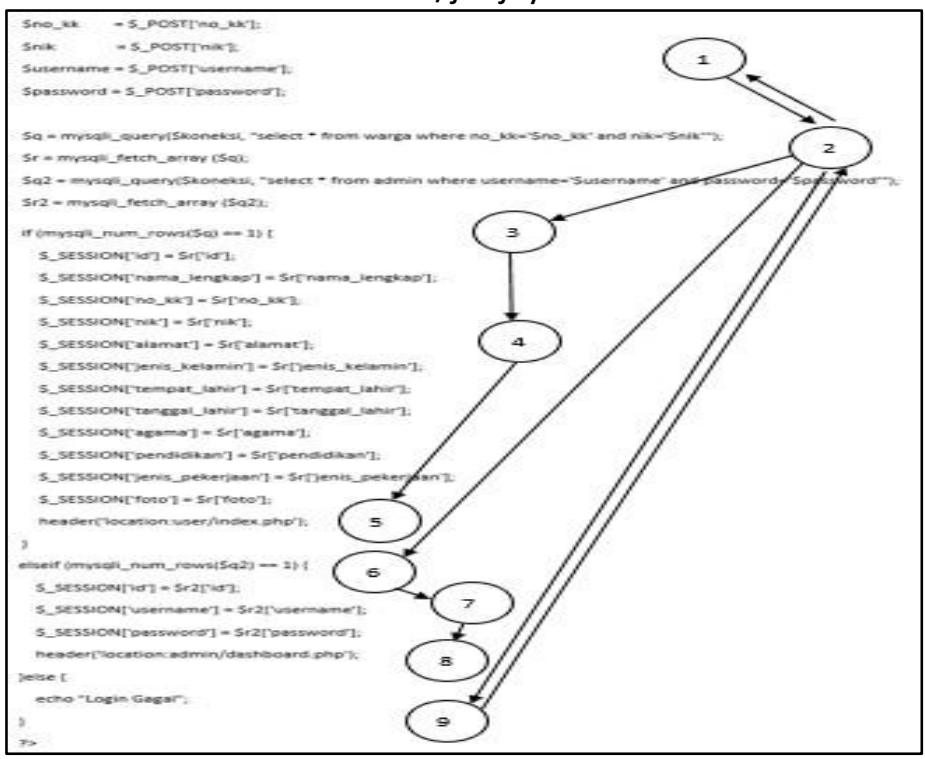

Gambar 20. White Box Testing Login

14. Flowgraph Proses Login

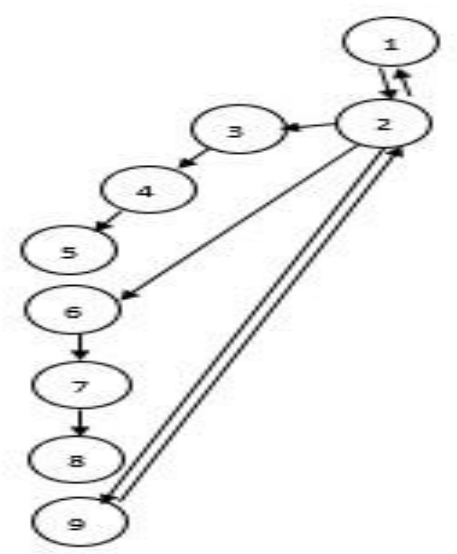

Gambar 21. Flowgraph Login

Berdasarkan gambar diatas, peneliti dapat menghitung kompleksitas siklometis dengan menggunakan rumus $\mathrm{V}(\mathrm{G})=\mathrm{E}-\mathrm{N}+2$. Sehingga perhitungan kompleksitas siklomatisnya adalah sebagai berikut: $\mathrm{V}(\mathrm{G})=\mathrm{E}-\mathrm{N}+2=10-9+2=3$

Berdasarkan alurnya, maka diperoleh independent path sebagai berikut :
a. Jalur $1=1-2-3-4-5$
b. Jalur $2=1-2-6-7-8$
c. Jalur $3=1-2-9-2-1$

15. Black Box Testing

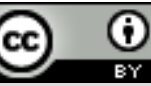

Ciptaan disebarluaskan di bawah Lisensi Creative Commons Atribusi 4.0 Internasional. http://journal.stmikjayakarta.ac.id/index.php/JMIJayakarta 
DOI: 10.52362/jmijayakarta.v1i1.367

Tabel 1. Black Box Testing

\begin{tabular}{|c|c|c|c|c|c|c|}
\hline Deskripsi & Test Case & Input & $\begin{array}{c}\text { Output } \\
\text { yang benar }\end{array}$ & $\begin{array}{l}\text { Kriteria } \\
\text { evaluasi }\end{array}$ & Output & Kesimpulan \\
\hline Pengujian Login & $\begin{array}{l}\text { Masukan } \\
\text { username dan } \\
\text { password } \\
\text { Klik Tombol } \\
\text { login } \\
\text { Tampil Login } \\
\text { berhasil }\end{array}$ & $\begin{array}{l}\text { Username dan } \\
\text { passwrord }\end{array}$ & $\begin{array}{l}\text { Berhasil } \\
\text { semua } \\
\text { tanpa } \\
\text { kesalahan }\end{array}$ & $\begin{array}{c}\text { Tampil } \\
\text { sesuai } \\
\text { dengan data } \\
\text { login }\end{array}$ & $\begin{array}{l}\text { Semua sudah } \\
\text { di akses dan } \\
\text { tidak error }\end{array}$ & Berhasil \\
\hline $\begin{array}{l}\text { Celk login sebagai } \\
\text { admin }\end{array}$ & $\begin{array}{ll}\text { - Masukan } \\
\text { username dan } \\
\text { password } \\
\text { Klik tombol login } \\
\text { - Tampil halaman } \\
\text { dashboard admin }\end{array}$ & $\begin{array}{l}\text { Username dan } \\
\text { password }\end{array}$ & $\begin{array}{c}\text { Muncul } \\
\text { tampilan } \\
\text { halaman } \\
\text { dashboard } \\
\text { admin }\end{array}$ & $\begin{array}{l}\text { Username } \\
\text { dan } \\
\text { password } \\
\text { sesuai } \\
\text { dengan data } \\
\text { login }\end{array}$ & $\begin{array}{c}\text { Muncul } \\
\text { tampilan } \\
\text { halaman } \\
\text { dashboard } \\
\text { admin }\end{array}$ & Berhasil \\
\hline $\begin{array}{l}\text { Cek login sebagai } \\
\text { warga }\end{array}$ & $\begin{array}{l}\text { Masukan } \\
\text { username dan } \\
\text { passtword } \\
\text { Klik tombol login } \\
\text { - Tampil halaman } \\
\text { warga }\end{array}$ & $\begin{array}{l}\text { Username dan } \\
\text { password }\end{array}$ & $\begin{array}{c}\text { Muncul } \\
\text { tampilan } \\
\text { halaman } \\
\text { warga }\end{array}$ & $\begin{array}{c}\text { Username } \\
\text { dan } \\
\text { password } \\
\text { sesuai } \\
\text { dengan data } \\
\text { login }\end{array}$ & $\begin{array}{c}\text { Muncul } \\
\text { tampilan } \\
\text { halaman } \\
\text { warga }\end{array}$ & Berhasil \\
\hline
\end{tabular}

16. Interpretasi hasil

Tabel 2. Interpretasi Hasil

\begin{tabular}{|c|c|c|c|}
\hline Functional & Usability & Acceptability & Efficiency \\
\hline $98,9 \%$ & $100 \%$ & $100 \%$ & $96,8 \%$ \\
\hline
\end{tabular}

Tabel 3. Rata-rata Hasil Uji Manfaat

\begin{tabular}{|c|c|c|c|c|c|}
\hline \multirow{4}{*}{ Functional } & \multirow{2}{*}{ Kriteria } & \multicolumn{3}{|c|}{ Pertanyaan } & Rata-rata \\
\hline & & P1 & P2 & P3 & \multirow{4}{*}{98,9} \\
\hline & $\mathbf{S}$ & 40 & 40 & 33,3 & \\
\hline & SS & 56,7 & 60 & 66,7 & \\
\hline \multicolumn{2}{|c|}{ Total } & 96,7 & 100 & 100 & \\
\hline \multirow{4}{*}{ Usability } & \multirow{2}{*}{ Kriteria } & \multicolumn{3}{|c|}{ Pertanyaan } & Rata-rata \\
\hline & & P4 & P5 & P6 & \multirow{4}{*}{100} \\
\hline & $\mathbf{S}$ & 6,7 & 50 & 40 & \\
\hline & $\mathbf{S S}$ & 93,3 & 50 & 60 & \\
\hline \multicolumn{2}{|c|}{ Total } & 100 & 100 & 100 & \\
\hline \multirow{4}{*}{ Acceptability } & \multirow{2}{*}{ Kriteria } & \multicolumn{3}{|c|}{ Pertanyaan } & Rata-rata \\
\hline & & $\mathbf{P 7}$ & PS & P9 & \multirow{4}{*}{100} \\
\hline & $\mathbf{S}$ & 40 & 30 & 46,7 & \\
\hline & $\mathbf{S S}$ & 60 & 70 & 53,3 & \\
\hline \multicolumn{2}{|c|}{ Tota1 } & 100 & 100 & 100 & \\
\hline \multirow{4}{*}{ Efficiency } & \multirow{2}{*}{ Kriteria } & \multicolumn{3}{|c|}{ Pertanyaan } & Rata-rata \\
\hline & & \multicolumn{2}{|c|}{$P_{10}$} & P11 & \multirow{4}{*}{96,8} \\
\hline & $\mathbf{S}$ & & & 50 & \\
\hline & $\mathbf{S S}$ & & & 50 & \\
\hline \multicolumn{2}{|c|}{ Total } & \multicolumn{2}{|c|}{93,6} & 100 & \\
\hline
\end{tabular}

\section{KESIMPULAN}

Peneliti dapat menyimpulkan bahwa dengan adanya Sistem Surat Elektronik Berbasis Website Dengan

Enkripsi Metode $m d 5$ pada Desa Wangon Banjarnegara, dapat disimpulkan sebagai berikut:

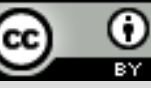

Ciptaan disebarluaskan di bawah Lisensi Creative Commons Atribusi 4.0 Internasional. http://journal.stmikjayakarta.ac.id/index.php/JMIJayakarta 
DOI: $10.52362 /$ jmijayakarta.v1i1.367

5.1.1 Sistem yang telah dibangun dapat meningkatkan efektifitas proses pembuatan surat pelayanan, baik surat keterangan maupun surat keterangan pada Desa Wangon Banjarnegara.

5.1.2.Dengan hasil pengujian hipotesis membuktikan bahwa proses sebelum dan sesudah adanya Sistem Surat Elektronik Berbasis Website Dengan Enkripsi Metode $m d 5$ memliki perbedaan yang sangat signifikan pada waktu, hal ini dapat dibuktikan dengan menggunakan metode OneSample Kolmogrov-Smirnov Test, dengan waktu sebesar 155,07 (sebelum menggunakan sistem) dan 11,87 (sesudah menggunakan sistem).

5.1.3 Dengan adanya enkripsi md5, maka data seperti NIK dan No KK pada proses login akan lebih aman.

\section{REFERENSI}

[1] Andrianto, S., \& Wijoyo, H. (2020). Rancang Bangun Sistem Informasi Siswa Berbasis Web di Sekolah Minggu Buddha Vihara Dharmaloka Pekanbaru. TIN: Terapan Informatika Nusantara, 1(2), 83-90.

[2] Ariyus, D. (2008). PENGANTAR ILMU KRIPTOGRAFI Teori Analisis dan Implementasi. Yogjakarta: C.V ANDI OFFSET. Britannica, E. (2015). Village. The Village. Ferguson, d. (2010). Ecrypction.

[3] Cahyono, Y., Purwanto, A., Sukanta, F. N. A., Fitriaty, H. W., Sihotang, M., \& Sugianto, A. (2020). Impact Of Service Quality, University Image And Students Satisfaction Towards Studentloyalty: Evidence From Indonesian Private Universities. Journal of Critical Reviews, 7(19), 3916-3924.

[4] Haudi, H. W., \& Cahyono, Y. (2020). Effect Of Product Innovation and Marketing Strategy on Consumer Purchase Decisions In Indonesia's Lightweight Roof Steel Industry. Journal of Critical Reviews, 7(13), 4147-4155.

[5] Lukmanul, H. (2004). Cara Cerdas Menguasai Layout, Desain dan Aplikasi Web. PT. Elex Media Komputindo.

[6] Pardosi, M. (2001). Electronic Letters. 18.

[7] Setyawati, E., Sarwani, Wijoyo, H., \& Soeharmoko, N. (2020). Relational Database Management System (Rdbms). Banyumas: Cv. Pena Persada.

[8] Wijoyo, H. (2020). Analisis Pengendalian Internal Dalam Pemberian Kredit Pada PT Bank Perkreditan Rakyat (BPR) Indomitra Mandiri. TIN: Terapan Informatika Nusantara, 1(4), 157-162.

[9] Wijoyo, H., \& Marpaung, S. L. (2020). The Influence of Quality Information and Reputation Of TIX ID Application Toward the Interest of Purchase Tickets Online in XXI Cinema Ciputra Seraya Mall Pekanbaru City. Jurnal Suluh Pendidikan, 8(2), 9-21.

[10] Yahya, M., \& Wijoyo, H. (2020). Developing School Information Program: Integrated Management System based on Character Value at SMP Negeri 9 Tapung. International Journal of Asian Education, $1(3), 179-186$.

[11] Wijoyo, H. (2020). RANCANG BANGUN SISTEM INFORMASI PENGGAJIAN DAN ABSENSI KARYAWAN MEGARA HOTEL PEKANBARU BERBASIS WEB. Ekonam: Jurnal Ekonomi, Akuntansi \& Manajemen, 2(2), 56-76. 